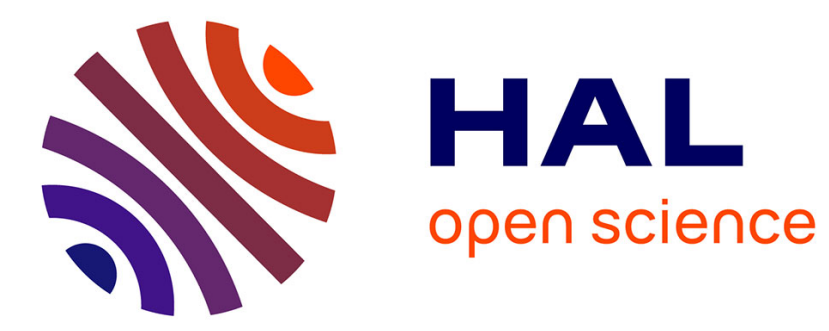

\title{
Selective uptake of alkaline earth metals by cyanobacteria forming intracellular carbonates
}

Nithavong Cam, Karim Benzerara, Thomas Georgelin, Maguy Jaber, Jean-Francois Lambert, Melanie Poinsot, Feriel Skouri-Panet, Laure Cordier

\section{- To cite this version:}

Nithavong Cam, Karim Benzerara, Thomas Georgelin, Maguy Jaber, Jean-Francois Lambert, et al.. Selective uptake of alkaline earth metals by cyanobacteria forming intracellular carbonates. Environmental Science and Technology, 2016, 50 (21), pp.11654-11662. 10.1021/acs.est.6b02872 . hal01383264

\section{HAL Id: hal-01383264 https://hal.sorbonne-universite.fr/hal-01383264}

Submitted on 18 Oct 2016

HAL is a multi-disciplinary open access archive for the deposit and dissemination of scientific research documents, whether they are published or not. The documents may come from teaching and research institutions in France or abroad, or from public or private research centers.
L'archive ouverte pluridisciplinaire HAL, est destinée au dépôt et à la diffusion de documents scientifiques de niveau recherche, publiés ou non, émanant des établissements d'enseignement et de recherche français ou étrangers, des laboratoires publics ou privés. 
4 Nithavong Cam, ${ }^{\dagger},{ }^{\ddagger}$ Karim Benzerara ${ }^{*},{ }^{\dagger}$ Thomas Georgelin, ${ }^{\ddagger}$ Maguy Jaber, ${ }^{\S}$ Jean-François

5 Lambert, $^{\ddagger}$ Mélanie Poinsot, ${ }^{\dagger \ddagger}$ Fériel Skouri-Panet $^{\dagger}$, Laure Cordier ${ }^{\#}$

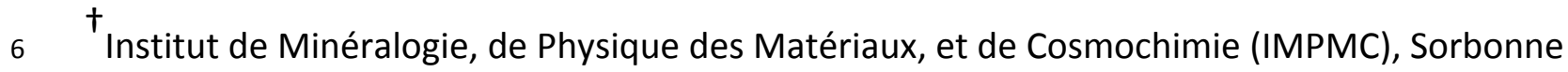

7 Universités, UPMC Univ Paris 06, UMR CNRS 7590, Muséum National d'Histoire Naturelle, IRD

8

9

UMR 206, 4 Place Jussieu, 75005 Paris, France

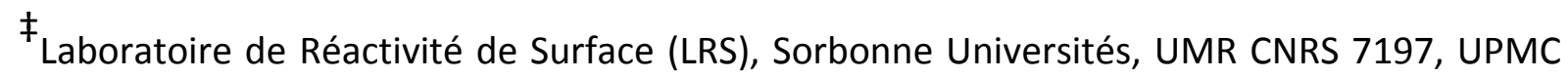

Univ Paris 06, 4 Place Jussieu, 75005 Paris, France

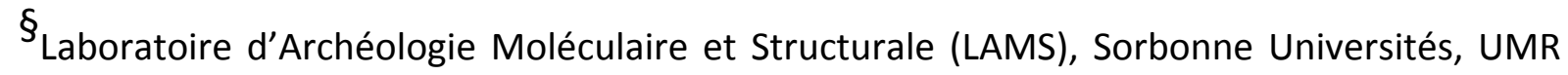

CNRS 8220, UPMC Univ Paris 06, 4 Place Jussieu, 75005 Paris, France

\# Institut de Physique du Globe de Paris (IPGP), Sorbonne Paris Cité - Université Paris Diderot,

UMR CNRS 7154, 1 rue Jussieu, 75238 Paris cedex 05, France

*Corresponding author: karim.benzerara@upmc.fr; Phone: +33144277542 


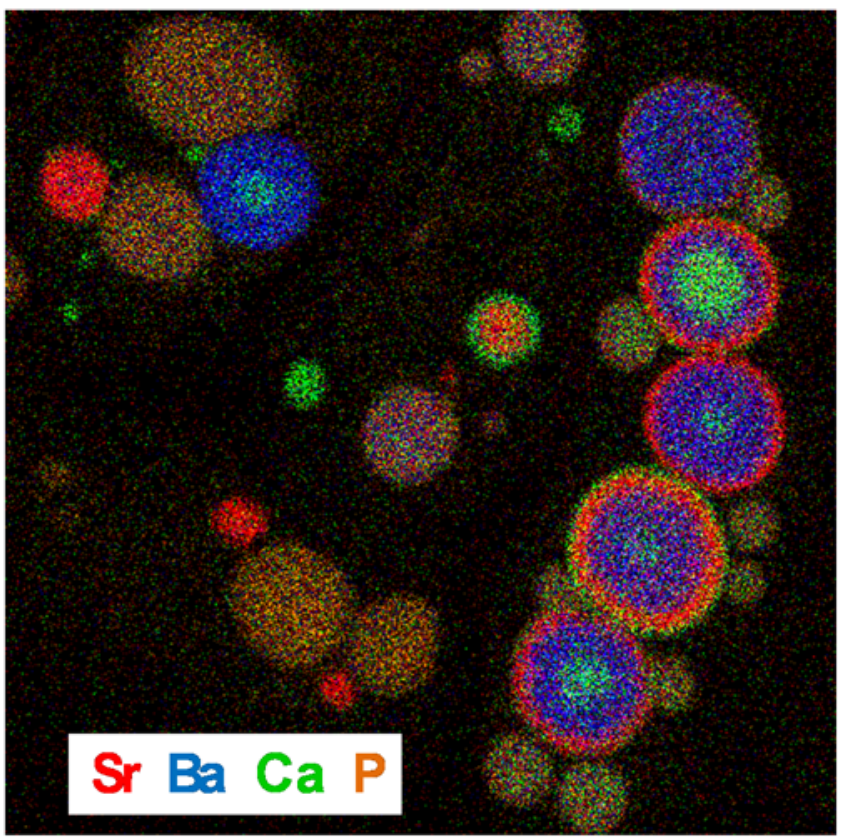

ABSTRACT

The uptakes of $\mathrm{Ca}$, Sr and Ba by two cyanobacterial strains, Cyanothece sp. PCC7425 and

Gloeomargarita lithophora, both forming intracellular carbonates, were investigated in laboratory cultures. In the culture medium BG-11 amended with $250 \mu \mathrm{M}$ of Ca and 50 or 250 
core-shell structures in the carbonates. This indicated that fractionation between alkaline earth metals was not inherent to intracellularly calcifying cyanobacteria but was likely a genetically-based trait of G. lithophora. Overall, the capability of G. lithophora to sequester preferentially $\mathrm{Sr}$ and $\mathrm{Ba}$ at high rates may be of considerable interest for designing new remediation strategies and better understanding the geochemical cycles of these elements.

\section{INTRODUCTION}

Alkaline earth metals are lithophile elements with diverse abundances in the Earth. Strontium $(\mathrm{Sr})$ has an average concentration of $316 \mathrm{ppm}$ in the upper continental crust and $8.1 \mathrm{mg} / \mathrm{L}$ in

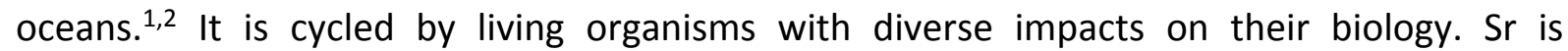
incorporated by plants, usually at the same rate as calcium (Ca), and can, at least in some cases, replace Ca to promote plant growth. ${ }^{3,4}$ At a low concentration, Sr stimulates bone formation and can be useful against osteoporosis. ${ }^{5,6}$ But at greater doses, Sr inhibits bone growth and can cause osteomalacia. ${ }^{7}$ Strontium 89 and 90 are major polluting nuclear fission products in environments contaminated by nuclear weapons tests and nuclear reactors accidents such as the ones of Fukushima or Chernobyl. ${ }^{8,9}$ Several (bio-)remediation strategies have therefore been developed to mitigate Sr dispersion and diverse (micro)organisms with unique bioremediation capabilities have been screened. ${ }^{10-12}$ Barium (Ba), has also received particular attention regarding its toxicity, in particular in the context of sludge deposits formed during oil production, which can contain high Ba concentrations. ${ }^{13,14}$ For example, Ba in its ionic form blocks Na-K pumps in cell membranes causing muscular paralysis in animals. ${ }^{15,16}$ Strontium and Ba have also been used as tracers for various (bio)geochemical processes. For example, $\mathrm{Sr} / \mathrm{Ca}$ and $\mathrm{Ba} / \mathrm{Ca}$ ratios have been suggested as good indicators for trophic level in 
foodwebs in terrestrial environments. ${ }^{17} \mathrm{Ba} / \mathrm{Ca}$ in otoliths has been used to infer where fish have lived. ${ }^{18}$ The $\mathrm{Ba} / \mathrm{Ca}$ ratio in foraminifers and other biomineralized carbonates has been used to trace past river discharge in the ocean. ${ }^{19}$ Finally, in oceans, pelagic barite $\left(\mathrm{BaSO}_{4}\right)$, formed in the water column, records changes in ocean productivity. ${ }^{20-22}$ Yet, the mechanisms of precipitation of pelagic barite and the microorganisms mediating this precipitation process are not known. ${ }^{23}$ Recent studies exploring the possibility to use Ba stable isotopes for deciphering the global $\mathrm{Ba}$ cycle call for further efforts to identify the biological processes affecting this element. ${ }^{21,22}$ Overall, there is a crucial need to better understand the biogeochemical cycle of $\mathrm{Sr}$ and $\mathrm{Ba}$ in order to strengthen the use of these proxies on one hand and design remediation strategies on the other hand..$^{24}$

Several organisms able to trap Sr and/or Ba have been discovered, including some bacteria, micro-algae and plants. ${ }^{11,25-35}$ Different mechanisms of sequestration may be involved. First, $\mathrm{Sr}^{2+}$ and $\mathrm{Ba}^{2+}$ may be adsorbed on the cell surface. ${ }^{25}$ Some organisms such as the algae Scenedesmus spinosus and Oedogonium sp. Nak 1001, the cyanobacteria Oscillatoria homogenea and Stigonema ocellatum NIES-2131 and the aquatic plant Egeria densa We2 show a particularly high affinity for $\mathrm{Sr}$, assigned to both sorption at the surface of the organisms (biosorption) and sequestration within the cells (bioaccumulation). (Fukuda, 2014; Dabbagh, 2007; Liu, 2014) $)^{11,26,27}$ The argument for sorption has been based on more or less complex modeling of the metal sequestration data; ${ }^{27}$ in simple cases, fixed amounts were fitted with a Langmuir isotherm. ${ }^{26}$ However, some of these results should be considered with caution, since deciphering the amount of earth alkaline element uptake and adsorption by microorganisms is sometime difficult. For example, Sternberg et al. ${ }^{36}$ showed that the apparent uptake of Ba by diatoms in laboratory cultures was actually due to sorption on Feoxyhydroxides formed in the cultures and not uptake by the cells. 
In other cases, alkaline earth metals are coprecipitated in minerals formed by organisms or adsorbed on the surfaces of these minerals. For example, the micro-alga Chlorella vulgaris and the bacteria Sporosarcina pasteurii (ATC 11 859) and Halomonas sp. induce extracellular precipitation of strontianite $\left(\mathrm{SrCO}_{3}\right) \cdot .^{28,30,31}$ In all these cases, the efficiency of $\mathrm{Sr}$ and/or Ba sequestration depends on the chemical conditions prevailing in the extracellular solution, including $\mathrm{pH}$ or the saturation of the solution with concerned mineral phases. These phases tend to incorporate $\mathrm{Ca}$ in addition to $\mathrm{Sr}$ and $\mathrm{Ba}$, depending on their concentrations in the extracellular solution and the relative solubilities of $\mathrm{Ca}-, \mathrm{Sr}$ - and Ba-mineral phases.

In contrast, some organisms accumulate Sr or Ba mostly intracellularly. The efficiency of the accumulation may depend less on the chemical conditions in the extracellular solution but more on the physiological status of the cells. ${ }^{37}$ For example, the yeast Saccharomyces cerevisiae traps $\mathrm{Sr}^{2+}$ within its vacuole, with $\mathrm{Sr}$ uptake involving similar molecular routes as those for $\mathrm{Ca}^{2+}$ transport. ${ }^{38}$ Interestingly, it has been shown that some organisms accumulate different alkaline earth metals in proportions that differ from those in the external solution. For example, $\mathrm{Sr} / \mathrm{Ca}$ and $\mathrm{Ba} / \mathrm{Ca}$ ratios measured in the algae Bryopsis maxima were significantly higher than in the extracellular solution. ${ }^{34}$ Last but not least, the desmid Closterium moniliferum forms barite $\left(\mathrm{BaSO}_{4}\right)$ and celestite $\left(\mathrm{SrSO}_{4}\right)$ within its vacuole by concentrating preferentially $\mathrm{Sr}$ and $\mathrm{Ba}$ over $\mathrm{Ca} .{ }^{35}$ This was explained by the lower solubilities of barite and celestite compared to calcium sulfate dihydrate. Radiolarians, ${ }^{39}$ green algae of the genus Chara $^{40}$ the ciliate genus Loxodes ${ }^{41}$ and xenophyophores (a group of foraminifers) are additional examples of organisms accumulating $\mathrm{Sr}$ and/or Ba as sulfates.$^{42}$ This selectivity is of high interest since it may offer strategies to remediate more efficiently $\mathrm{Sr}$ and/or Ba from Ca-rich effluents. Moreover, some of these microorganisms have been suggested to drive the formation of pelagic barite in oceans, although their abundance may be too low. ${ }^{23}$ 
Interestingly, most of the organisms studied so far showing this selectivity upon alkaline earth metal uptake are eukaryotes. Therefore, the recently discovered cyanobacterium Gloeomargarita lithophora may provide an original model in this context. ${ }^{43}$ Indeed, G. lithophora cells form intracellular $\mathrm{Ca}$-, $\mathrm{Sr}$ - and $\mathrm{Ba}$-carbonate granules in solutions containing a relatively high Ca concentration of $50 \mu \mathrm{M}$ and low Ba and Sr concentrations of 0.001 and $0.013 \mu \mathrm{M}$, respectively. This preferential uptake of $\mathrm{Sr}$ and Ba over Ca by G. lithophora was suggested based on electron microscopy observations of a highly diverse microbial assemblage. ${ }^{43} \mathrm{G}$. lithophora can accumulate a large amount of alkaline earth metal up to several fmoles per cell. ${ }^{44}$ However, no detailed study has been performed yet on the uptake kinetics of Sr and Ba by isolated G. lithophora cells in a controlled culture medium.

The origin of this differential fractionation of alkaline earth metals remains enigmatic for G. lithophora. In vitro abiotic syntheses of carbonates similar to the granules observed in cyanobacteria showed no differential fractionation of $\mathrm{Ca}, \mathrm{Sr}$ and $\mathrm{Ba}$ between the solution and the mineral phase. ${ }^{45}$ This suggested that biological processes rather than physicochemical parameters, such as solubility differences between alkaline earth carbonates and/or different precipitation kinetics are responsible for this selectivity between alkaline earth metals in $G$ lithophora cells. However, it is not known whether this selectivity is intrinsically related to the capability of G. lithophora to form intracellular carbonates. Interestingly, some other cyanobacterial species, phylogenetically distant from G. lithophora but forming intracellular carbonates, ${ }^{46}$ were recently discovered but their capability to selectively sequester $\mathrm{Sr}$ and $\mathrm{Ba}$ over Ca has not been tested yet. If they showed such a capability, they may play a yet overlooked role in $\mathrm{Ba}$ and $\mathrm{Sr}$ geochemical cycles since they have been found in many locations worldwide and diverse continental environments. ${ }^{47}$ 
Here, we followed the time-evolution of the uptake of $\mathrm{Ca}$, $\mathrm{Sr}$ and $\mathrm{Ba}$ by cells of $\mathrm{G}$. lithophora and Cyanothece sp. PCC 7425 cultured in BG-11 amended with Sr and Ba. Both cyanobacterial strains form intracellular carbonate granules. We quantified and compared the uptakes of $\mathrm{Ba}$, Sr and $\mathrm{Ca}$ by the two cyanobacterial strains and assessed their cellular distributions.

\section{EXPERIMENTAL}

\section{Cyanobacterial strains and culture conditions}

Two cyanobacterial strains were tested for Sr and Ba uptake: 1) Gloeomargarita lithophora C7 enriched and described by Couradeau et al. ${ }^{43}$ and Benzerara et al. ${ }^{46} ; 2$ ) the axenic strain Cyanothece sp. PCC 7425 was obtained from the Pasteur Collection of Cyanobacteria. ${ }^{48}$ Both strains were cultured in BG-11 medium at $30{ }^{\circ} \mathrm{C}$ under continuous light $\left(5-10 \mu \mathrm{mol} . \mathrm{m}^{2} . \mathrm{s}^{-}\right.$ $\left.{ }^{1}\right) .{ }^{48} \mathrm{BG}-11$ medium contained $17.65 \mathrm{mM}$ of $\mathrm{NaNO}_{3}, 0.18 \mathrm{mM}$ of $\mathrm{K}_{2} \mathrm{HPO}_{4}, 0.3 \mathrm{mM}$ of $\mathrm{MgSO}_{4}$, $0.25 \mathrm{mM}$ of $\mathrm{CaCl}_{2}, 0.03 \mathrm{mM}$ of citric acid, $0.03 \mathrm{mM}$ of ferric ammonium citrate, $0.003 \mathrm{mM}$ EDTA, $0.38 \mathrm{mM}$ of $\mathrm{Na}_{2} \mathrm{CO}_{3}$, and trace minerals. ${ }^{48}$ Strontium and barium were added to $\mathrm{BG}-11$ as chloride salts (Sigma Aldrich) at final concentrations of 50 or $250 \mu \mathrm{M}$. Sulfates may affect the solubility of $\mathrm{Sr}$ and $\mathrm{Ba}$. However, this did not seem to play a significant role in their bioavailability here since: 1 ) measured dissolved $\mathrm{Sr}$ and $\mathrm{Ba}$ concentrations at $\mathrm{t}=0$ (i.e., when cultures were inoculated) were approximately similar to added ones; 2) Sr and Ba were clearly incorporated by cyanobacteria as shown by microscopy analyses and 3) the changes with time of dissolved $\mathrm{Sr}$ and Ba concentrations were very different between strains suggesting that concentrations of $\mathrm{Sr}$ and Ba were not buffered by the precipitation of earth alkaline sulfates in the culture medium. Evaporation was compensated by daily addition of sterile milli-Q water. The optical density (OD) of the suspensions was measured at $730 \mathrm{~nm}$. The precision on 
OD measurements was 0.005 . The relationships between OD and cell density were estimated as $9 \times 10^{7}$ and $3 \times 10^{7}$ cell. $\mathrm{mL}^{-1}$.OD unit ${ }^{-1}$ for $\mathrm{G}$. lithophora and Cyanothece sp., respectively. The relation between OD and cell dry mass was $3.65 \times 10^{-4}$ g.OD unit ${ }^{-1}$ for $1 \mathrm{~mL}$ of $\mathrm{G}$. lithophora culture.

For bulk chemical analyses, $500 \mu \mathrm{L}$ of culture were centrifuged at 5,000 g for $10 \mathrm{~min}$. The $\mathrm{pH}$ of the supernatant was systematically measured. The precision on $\mathrm{pH}$ measurement was 0.01 . Time variations of the $\mathrm{pH}$ in non-inoculated sterile controls were up to $0.1 \mathrm{pH}$ units. Supernatants were then filtered at $0.22 \mu \mathrm{m}$ and acidified by addition of $2 \mu \mathrm{L}$ of $\mathrm{HNO}_{3}$ (70\%) in order to measure dissolved $\mathrm{Ca}, \mathrm{Sr}$ and $\mathrm{Ba}$ concentrations. For scanning transmission electron microscopy (STEM) observations, cell pellets were washed three times with milli-Q water before suspension in $500 \mu \mathrm{L}$ of milli-Q water and deposition of $3 \mu \mathrm{L}$ on carbon-coated 200-mesh copper grids.

\section{ICP-AES measurements}

Concentrations of dissolved Ca, Sr, Ba were measured using a Thermo Scientific ${ }^{\mathrm{TM}}$ iCAP $^{\mathrm{TM}} 6200$ ICP emission spectrometer equipped with a cetac ASX-520 autosampler. Ten milliliters of $2 \%$ $\mathrm{HNO}_{3}$ were added to $300 \mu \mathrm{L}$ of acidified supernatants. Taking into account dilutions of the samples before ICP-AES measurements, detection limits for $\mathrm{Ca}, \mathrm{Sr}$ and $\mathrm{Ba}$ concentrations were $0.37,0.05$ and $0.07 \mu \mathrm{M}$, respectively.

Uptake rates normalized by the number of cells were determined for each time step as followed: $\quad \frac{\left[X^{2+}\right]_{t-1}-\left[X^{2+}\right]_{t}}{\text { average cell density between } t_{-1} \text { and } t} / t-t_{-1}$

Where $\mathrm{X}$ denotes one chemical element, $\mathrm{t}$ and $\mathrm{t}-1$ are two consecutive sampling times.

\section{Scanning transmission electron microscopy (STEM) and energy dispersive $x$-ray} spectrometry (EDXS) analyses 
STEM analyses were performed in the high angle annular dark field (HAADF) mode using a JEOL $2100 F$ operating at $200 \mathrm{kV}$ and equipped with a field emission gun and a JEOL EDXS detector. Semi-quantitative analyses of EDXS spectra were processed using the JEOL Analysis Station software following Li et al. procedure. ${ }^{44}$ This was based on the use of K-factors. From this, the atomic percentage of selected element was assessed (here $\mathrm{Ca}, \mathrm{Mg}$, $\mathrm{Sr}$ and $\mathrm{Ba}$ in the carbonates; $\mathrm{Ca}, \mathrm{Mg}, \mathrm{Sr}, \mathrm{Ba}, \mathrm{K}$ and $\mathrm{P}$ in polyphosphates).

\section{RESULTS AND DISCUSSION}

\section{Kinetics of Ca, Sr and Ba uptakes by G. lithophora and Cyanothece sp.}

G. lithophora cells grew with comparable generation times (92 \pm 8 h vs $108 \pm 2 h$ ) and up to similar OD values ( 0.6) and extracellular pH ( 9.3) in BG-11 amended with $50 \mu \mathrm{M} \mathrm{Sr}$ and $\mathrm{Ba}$ as in BG-11 without Sr and Ba (Figure S1; Table S1).

Extracellular concentrations of dissolved $\mathrm{Ca}, \mathrm{Sr}$ and $\mathrm{Ba}$ measured immediately after their addition to BG-11 were $236 \pm 8.8,45 \pm 0.8$ and $42 \pm 0.4 \mu \mathrm{M}$, respectively (Figure 1 ). The slight differences with expected concentrations ( $250 \mu \mathrm{M}, 50 \mu \mathrm{M}$ and $50 \mu \mathrm{M}$, respectively) may be due to dilution errors and/or some sulfate precipitation. The uptake of alkaline earth metals by $G$. lithophora cells occurred in three consecutive stages. During the first stage, within $175 \mathrm{~h}$, the concentration of dissolved Ba decreased down to the detection limit $(0.07 \mu \mathrm{M})$. During this stage, the concentration of Ca decreased by about $10 \%$ only, while the Sr concentration remained constant. During the second stage, the dissolved Ba concentration remained below the detection limit, while the $\mathrm{Sr}$ concentration decreased down to the detection limit $(0.05 \mu \mathrm{M})$ in $50 \mathrm{~h}$. During this stage, the concentration of dissolved Ca remained constant. Finally, in a last stage, the Sr and Ba concentrations remained below detection limits, while 
the concentration of dissolved Ca decreased down to $43 \mu \mathrm{M}$ (this value was reached after $384 \mathrm{~h}$ of total incubation time). The durations of the different stages varied by $8-31 \%$ between replicates but they always followed the same order (Figure S2).

The uptake rates of alkaline earth metals ranged between 0.02 and $0.10 \mathrm{fmol}^{-\mathrm{h}^{-1}}$.cell ${ }^{-1}$ (Figure S3). Taking replicates into account, average uptake rates were estimated to $0.058 \pm 0.015 \mathrm{fmol} \cdot \mathrm{h}^{-1}$.cell ${ }^{-1}$ for $\quad$ Ba, $\quad 0.049 \pm 0.021 \mathrm{fmol}^{-h^{-1}}$.cell ${ }^{-1}$ for $\quad \mathrm{Sr}$ and $0.026 \pm 0.010 \mathrm{fmol}^{-\mathrm{h}^{-1} \text {.cell }}{ }^{-1}$ of Ca. Uptake rates were therefore in the same order of magnitude for the different alkaline earth metals, with a slight decrease over the duration of the culture.

In Cyanothece sp. PCC 7425 cultures with Sr and Ba at $50 \mu \mathrm{M}$, the optical density increased up to 1 in $350 \mathrm{~h}$, while the $\mathrm{pH}$ increased and plateaued at around 9 after 250 hours (Figure S4). The growth in cultures with Sr and Ba was slightly faster than in cultures without $\mathrm{Sr}$ and $\mathrm{Ba}$ ( 63 h vs 82 h; Figure S5).

The different stages of $\mathrm{Ba}, \mathrm{Sr}$ and $\mathrm{Ca}$ uptake evidenced for $\mathrm{G}$. lithophora were not observed for Cyanothece sp. (Figure 2). In contrast, the concentration of dissolved Ca decreased first. The concentrations of dissolved $\mathrm{Sr}$ and $\mathrm{Ba}$ only decreased in a later stage, when dissolved $\mathrm{Ca}$ concentration had fallen down to about $50 \mu \mathrm{M}$, i.e. similar to initial concentrations of $\mathrm{Sr}$ and Ba.

Overall, only G. lithophora showed preferential uptakes of Ba over Sr and Sr over Ca. This selectivity for alkaline earth metals was therefore not related to intracellular carbonate formation. Based on in vitro syntheses, Cam et al. ${ }^{45}$ showed that the precipitation of amorphous carbonates alone could not fractionate significantly $\mathrm{Sr}, \mathrm{Ba}$ and $\mathrm{Ca}$ and suggested that some other mechanisms must be operating in G. lithophora. The present study supports this hypothesis and reveals that the molecular machinery allowing selective fractionation of 
alkaline earth metals exists in G. lithophora but not Cyanothece sp. Interestingly, this process of alkaline earth metals sequestration by carbonates in solutions undersaturated with $\mathrm{Sr}$ and Ba carbonates was observed in Lake Leman in relation with the picoplankton. ${ }^{49}$ Whether microorganisms with capabilities similar to those of G. lithophora occur in Lake Leman will have to be determined in the future.

\section{Cellular distribution of $\mathrm{Ca}, \mathrm{Sr}$ and $\mathrm{Ba}$ in G. lithophora and Cyanothece sp.}

The evolution of the chemical composition of intracellular carbonates was assessed by STEMHAADF. At 75 h, i.e., during Ba uptake, G. lithophora cells had divided once on average (Figure 1). The majority of the carbonate granules in the cells (55\% out of 31 observed granules) showed a bright outer shell around a dark core (Figure 3). Accordingly, EDXS analyses indicated that the core was rich in $\mathrm{Ca}$ and the brighter outer shell was rich in $\mathrm{Ba}$. The thickness of the Ba-shell measured $80 \pm 34 \mathrm{~nm}$ (11 analyzed particles). Considering the relative thicknesses of the shells, the diameters of the cores and the $\mathrm{Ca} / \mathrm{Ba}$ ratios measured on the cores (Figure 3), EDXS measurements were consistent with pure Ca-carbonate cores covered by Ba-carbonate outer shells. Moreover, in the same cells, some carbonate granules ( $25 \%$ over 31 counted granules) contained only Ba with no Ca-rich cores, while other granules (20\%) contained only Ca with no outer Ba-carbonate shell. In accordance with bulk chemical analyses of the solutions, mixed $\mathrm{Ca}$ - and Ba-containing carbonate granules were interpreted as resulting from the growth of Ba-carbonates during the first 75 hours around $\mathrm{Ca}$-carbonate cores. Ca-carbonate cores formed in the pre-culture grown in Ba- and Sr-deprived BG-11. In the meantime, some new Ba-carbonate granules nucleated within the cells and some preexisting Ca-carbonate granules did not grow further. Two concurrent nucleation pathways occur for barium carbonates: one forming particles de novo by homogeneous (in solution) or 
heterogeneous (on organic template) nucleation and the other one by heterogeneous nucleation on the surface of preexisting calcium carbonates. The heterogeneous nucleation is followed by a two-step growth: very rapid 2-D growth on the underlying particle resulting in complete coverage, followed by slower growth perpendicular to the surface.

Cells contained a volume of $0.064 \pm 0.043 \mu \mathrm{m}^{3}$.cell ${ }^{-1}$ of both Ca- and Ba-carbonates on average. After $75 \mathrm{~h}$ of cell growth, there were $4.57 \times 10^{6}$ cell.mL ${ }^{-1}$ in the cultures, accounting for a total uptake of $12.75 \times 10^{-9} \mathrm{~mol}^{\mathrm{mL}} \mathrm{m}^{-1}$ of Ba, i.e., $2.8 \mathrm{fmol}^{\mathrm{c}} \mathrm{cell}{ }^{-1}$ of Ba. If all this Ba was trapped as carbonates only, this would represent a total volume of $0.151 \mu \mathrm{m}^{3}$ per cell based on a density of $4.3 \mathrm{~g} . \mathrm{cm}^{-3}$ for amorphous Ba-carbonate. ${ }^{50}$ This is significantly more than the volume of carbonates observed by STEM, suggesting that only a fraction of $\mathrm{Ba}(\sim 1 / 3)$ was contained in carbonate granules.

G. lithophora cells also contained phosphorus-rich granules (Figure 3), which were identified as polyphosphates (PolyP) by Li et al..$^{44}$ The preferential uptake of Ba over $\mathrm{Sr}$ and Ca was not restricted to carbonate granules only since in addition to $\mathrm{Mg}$, $\mathrm{Ca}$ and $\mathrm{K}$, PolyP granules contained Ba in cells sampled during the Ba uptake stage (Figure 3; Figure S6). Ba content ranged between 30 and $70 \%$ (expressed as an atomic proportion over $\mathrm{Mg}+\mathrm{Ca}+\mathrm{Sr}+\mathrm{Ba}$ ) in PolyP. EDXS maps showed that Ba concentration was high in carbonate and PolyP granules (Figure 3) but below detection limits in the rest of the cells (Figure 3). Therefore, most of Ba was accumulated in PolyP and carbonate granules with possibly some minor amount complexed by proteins.

At 244 h, i.e., during the Sr uptake stage (Figure S2), Sr-carbonates were detected within the cells (Figure 3). Some particles showed a Ca-rich core and two outer superimposed shells, a Ba-rich intermediate shell and a Sr-rich external shell. Some carbonate granules containing mostly Sr, with minor amounts of Ca and Ba (Figure 3), were also observed. Polyphosphates 
granules were homogeneous in composition and contained mostly $\mathrm{Mg}, \mathrm{K}, \mathrm{Sr}$ and $\mathrm{Ba}$, sometimes with small, almost undetectable amounts of Ca. Their compositions were variable but most of them showed an increased proportion of $\operatorname{Sr}(15 \%$ on average; Figure S6).

Finally, at $310 \mathrm{~h}$, during the Ca uptake stage, granules showed a Ca-rich core and three successive shells rich in $\mathrm{Ba}$, Sr and $\mathrm{Ca}$, respectively, from the center to the periphery (Figure 3). Other types of granules were observed but always with the same order for the shells, e.g., Ca-shells over Sr-cores; Ca-cores only; Sr-shells over Ba-shells. Despite some variability in chemical composition from cell to cell, polyphosphate granules contained higher concentrations of Ca than during the Sr uptake stage (27\% vs. $6 \%$ during the Sr uptake stage; Figure S6).

Overall, we observed in G. lithophora cells 1) newly nucleated carbonate granules containing only one alkaline earth metal, named "simple", and 2) "composite" carbonate granules with outer shells containing Ba, Sr or Ca. "Simple" granules had a mean diameter of $215 \pm 91 \mathrm{~nm}$ with a normal distribution (Figure S7), very similar to that observed for Ca-carbonate granules $(217 \pm 64 \mathrm{~nm})$ in G. lithophora cultured in BG-11 with no Sr and Ba. ${ }^{44}$ In contrast, "composite" granules showed larger diameters, i.e. $415 \pm 115 \mathrm{~nm}$, and measured up to $650 \mathrm{~nm}$ in diameter (Figure S7).

For a comparison, Cyanothece sp. cells were also observed by STEM-HAADF at 244 h, i.e. at a stage when they were mostly taking up $\mathrm{Ca}$, and at $310 \mathrm{~h}$, i.e. during the $\mathrm{Ca}, \mathrm{Ba}$ and $\mathrm{Sr}$ uptake stage (Figure 4; Figure S8). In agreement with bulk chemical measurements, intracellular carbonates within these cells mostly contained Ca (82.2 $\pm 6.2 \%$ atomic proportion of Ca over $\mathrm{Mg}+\mathrm{Ca}+\mathrm{Sr}+\mathrm{Ba}$ ) with several percent of $\mathrm{Sr}$ and $\mathrm{Ba}$ (on average 7.8 and $7.3 \%$ at $310 \mathrm{~h}$, of $\mathrm{Sr}$ and Ba respectively). However, in contrast to G. lithophora, Cyanothece sp. cells showed chemically homogeneous carbonate granules with no core-shell structure. Polyphosphates 
also mostly contained Ca with only a few percent of $\mathrm{Sr}$ and $\mathrm{Ba}$ at 244h (3\% of Sr and Ba) and a slightly higher content in Ba and Sr at $310 \mathrm{~h}$ (11 and 5\% respectively; Figure S8).

\section{Origin of selectivity for alkaline earth metals in G. lithophora}

In this study, both $G$. lithophora and Cyanothece sp. strains incorporated alkaline earth metals massively when cultured in BG-11 amended with $\mathrm{Sr}$ and Ba. However, only Gloeomargarita lithophora achieved a sequential and preferential uptake of $\mathrm{Ba}$ over $\mathrm{Sr}$ and $\mathrm{Sr}$ over $\mathrm{Ca}$. This was detected by marked changes in the chemical composition of the extracellular solution as well as in the chemical composition of the intracellular carbonate and polyphosphate granules.

A preferential uptake of $\mathrm{Sr}$ and/or Ba over Ca has been observed previously in the desmid green algae Closterium moniliferum..$^{35}$ The algae concentrate Ba and Sr in their vacuoles as Baand Sr-sulfate crystals. Based on the large solubility differences of $\mathrm{Ca}$-, Sr- and Ba-sulfates, Krejci et al. ${ }^{35}$ suggested that the preferential uptake of $\mathrm{Sr}$ and $\mathrm{Ba}$ over Ca was due to an elemental fractionation induced by sulfate precipitation within the cells. In contrast, several observations strongly argue against a fractionation of alkaline earth metals by mineral precipitation in G. lithophora and favor the involvement of another biochemical process: 1) Cam et al. ${ }^{45}$ showed that the solution/solid fractionations were very similar for $\mathrm{Sr}$, Ba and Ca for in vitro precipitation of amorphous carbonates; 2) no Sr-, Ba and/or Ca-sulfate phase precursor to the carbonates, which could induce some distinct fractionation between $\mathrm{Sr}$, Ba and $\mathrm{Ca}$, was observed within $\mathrm{G}$. lithophora; 3) the composition of PolyP followed the same succession of uptake stages as the carbonates; 4) Cyanothece sp. did not fractionate Sr, Ba and Ca distinctly, although it also formed intracellular carbonates. 
Unfortunately, no biochemical process explaining such a selectivity between alkaline earth elements is presently known. All known biomolecules have either a similar affinity for $\mathrm{Ca}$ and $\mathrm{Sr}$ and a lower affinity for $\mathrm{Ba}$, or a high affinity for $\mathrm{Ca}$ and lower affinities for $\mathrm{Sr}$ and $\mathrm{Ba} .{ }^{52-56}$ Future work based for example on genetics and comparative genomics between strains incorporating alkaline earth metals selectively and others not able of this selective uptake may provide some clues about the biochemical origin of this selectivity.

\section{Implications for bioremediation and the geochemical cycles of $\mathrm{Ba}$ and $\mathrm{Sr}$}

The masses of intracellular Ba, $\mathrm{Ca}$ and $\mathrm{Sr}$ in G. lithophora cells were estimated as a function of time and normalized to the total cell dry mass (Figure S9). For Ba, there was first an increase when uptake was higher than "dilution" by cell division, then a plateau and finally a decrease when no Ba was left in the extracellular solution but cell division was continuing. Baryum mass reached a maximum of $16 \%$ of the total cell dry mass. Similar evolutions were observed for Sr and Ca with a maximum of $7 \%$ for the mass of Sr over the total cell weight.

Cultures were also conducted in BG-11 containing higher initial $\mathrm{Sr}$ and $\mathrm{Ba}$ concentrations $(245 \mu \mathrm{M})$. The $\mathrm{pH}$ and the $\mathrm{OD}$ increased similarly to what was observed in cultures with $50 \mu \mathrm{M}$ of $\mathrm{Sr}$ and Ba with a slightly longer generation time (Figure S10). Similarly to what was observed in the presence of $50 \mu \mathrm{M}$ of Sr and Ba, three uptake stages were detected (Figure S11). The concentration of dissolved Ba decreased first, and this step was followed by decreases of the concentrations of dissolved Sr and finally of dissolved Ca. In $650 \mathrm{~h}$, cells took $245 \mu \mathrm{M}$ of Ba, $245 \mu \mathrm{M}$ of Sr and $245 \mu \mathrm{M}$ of $\mathrm{Ca}$. Under these conditions barium and strontium masses reached up to a maximum of $22 \%$ and $8 \%$ of total cell dry mass, respectively (Figure 5 ).

Altogether, these results show that G. lithophora can strongly accumulate Ba and $\mathrm{Sr}$ while staying viable and showing high selective affinity for these alkaline earth metals over Ca. 
Moreover, this selective uptake seems to operate even at low $\mathrm{Sr} / \mathrm{Ca}$ or $\mathrm{Ba} / \mathrm{Ca}$ ratios in the extracellular solution since Ba and Sr are taken up preferentially down to their detection limits ( 0.07 and $0.05 \mu \mathrm{M}$, respectively, corresponding to a molar ratio between 2.0 and $2.9 \times 10^{-4}$ with respect to $\mathrm{Ca}$ ).

Several micro-organisms have been studied for their capability to store $\mathrm{Sr}$ or Ba with the ultimate scope of designing bioremediation strategies (Table 1). In the present study, only minimum uptake capabilities were determined for $G$. lithophora since our cultures exhausted the amount of Sr and Ba provided, without any evidence that they had reached their ultimate storage capacity. G. lithophora showed unique uptake capabilities per cell. For example, a cell of the desmid Closterium moniliferum had greater $\mathrm{Sr}$ uptake capability than a cell of G. lithophora (140 vs. $35 \mathrm{fmol}^{-c e l l}{ }^{-1}$ ) but when normalized to the cell mass, G. lithophora showed a much higher uptake $(75 \mathrm{mg} / \mathrm{g}$ vs $2 \mathrm{mg} / \mathrm{g})$.

Fukuda et al. (2014) ${ }^{14}$ screened 188 different strains of macro- and micro-organisms from aquatic environments in search for good candidates to bioremediate radionuclide contaminations, including isotopes of strontium. Cyanobacteria showed particularly high uptake capabilities (Fukuda, 2014). ${ }^{14}$ They suggested that this may be due to some particular properties of their cell walls without further proof. Cyanobacteria forming intracellular carbonates, including but not restricted to G. lithophora, meet the different criteria mentioned by Fukuda et al. ${ }^{11}$ as good candidates for bioremediation. Moreover, they have been isolated from different places around the world and can grow at varied temperatures. ${ }^{46}$ Some are thermophilic, some mesophilic; some live in high altitude lakes, while others live in soils. Among intracellularly calcifying cyanobacteria, Gloeomargarita lithophora is particularly interesting: it preferentially sequesters $\mathrm{Ba}$ and $\mathrm{Sr}$ over $\mathrm{Ca}$, which offers a unique solution to the general problem of remediating these pollutants in aqueous environments with naturally 
high Ca concentrations. However, if cells are used directly in bioremediation strategies, several parameters will have to be determined in the future to fully assess the potential of G. lithophora such as its maximum uptake capability for $\mathrm{Sr}$ and its resistance to radioactivity from ${ }^{89} \mathrm{Sr}$ or ${ }^{90} \mathrm{Sr}$. Alternatively, it will be important to understand the precise molecular mechanisms involved in the preferential uptake of $\mathrm{Sr}$ and $\mathrm{Ba}$ vs Ca which may inspire the design of new cell-free remediation strategies, complementing those already existing and using non-biological materials, such as synthetic chelators or ion exchangers. ${ }^{10}$ In parallel, the present study has implications for the geochemical cycles of Sr and Ba. First, it shows that some cyanobacteria concentrate significantly $\mathrm{Sr}$ and $\mathrm{Ba}$ in connection with the formation of carbonates and not sulfates as usually considered. With the aim of explaining the formation of pelagic barite in oceans, Gonzalez-Munoz et $a l .{ }^{57}$ showed that several heterotrophic marine bacterial strains could induce the precipitation of barite. However, they needed to culture them at relatively high Ba concentrations $(2 \mathrm{mM})$. The existence of primary producers accumulating Ba significantly, such as G. lithophora may provide such a rich source of Ba. Moreover, Peek and Clementz ${ }^{17}$ compiled numerous $\mathrm{Sr} / \mathrm{Ca}$ and $\mathrm{Ba} / \mathrm{Ca}$ measurements on biological samples. They suggested that most of the variations of these ratios were accounted by (abiotic) variations in geochemical sources of alkaline earth metals in terrestrial environments, while high accumulation of $\mathrm{Sr}$ and $\mathrm{Ba}$ by microorganisms tended to control $\mathrm{Sr} / \mathrm{Ca}$ and $\mathrm{Ba} / \mathrm{Ca}$ ratios at the base of marine foodwebs. Here, we show that microorganisms such as $G$. lithophora may play a similar role in continental environments. As a conclusion, the biochemical process evidenced in G. lithophora in the present study might have an important impact on the geochemical cycles of $\mathrm{Sr}$ and $\mathrm{Ba}$ if it is widespread. This will need to be assessed by future studies. 


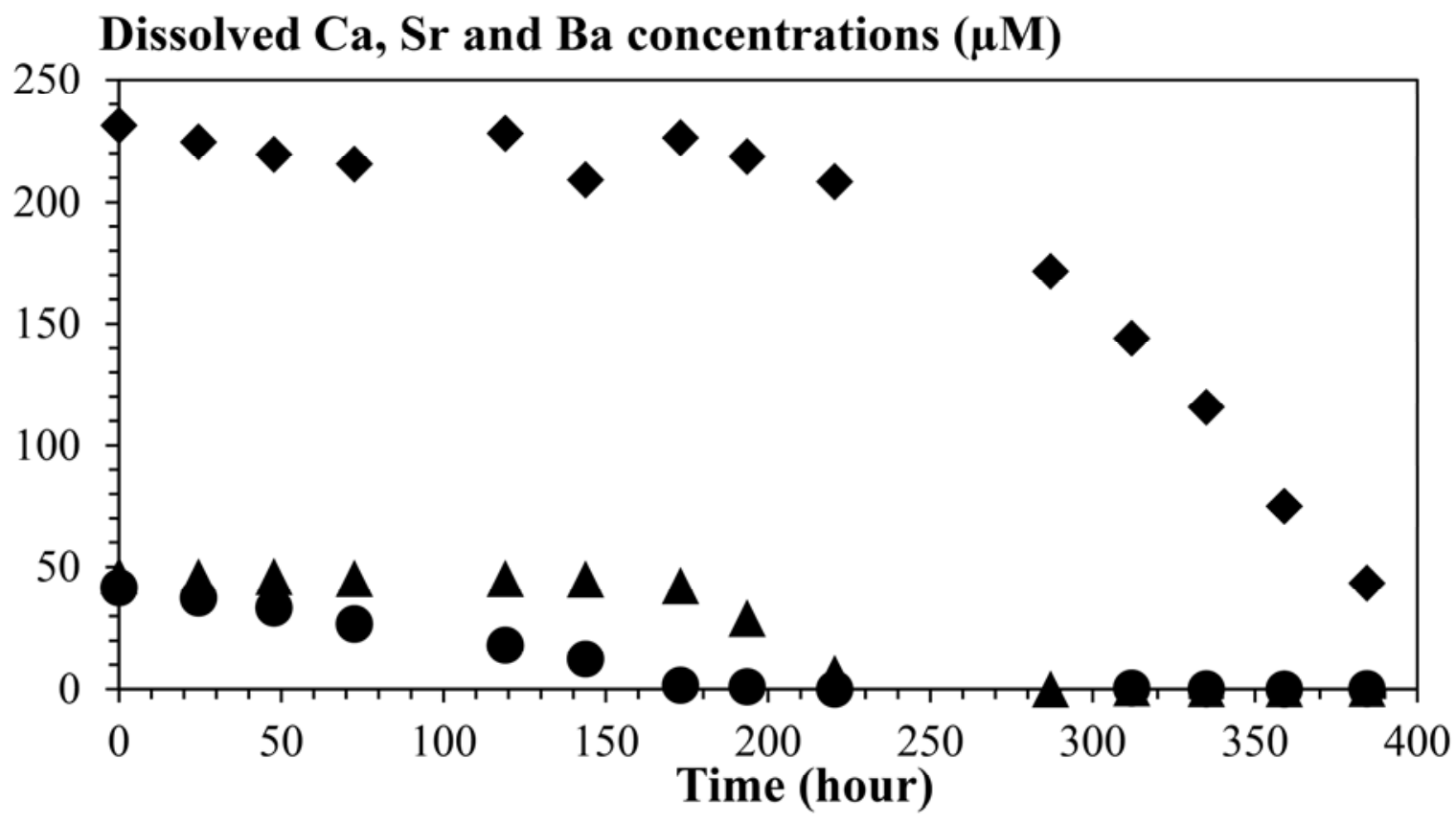

Figure 1. Time evolution of the concentrations of dissolved $\mathrm{Ca}$ (diamonds), $\mathrm{Sr}$ (triangles) and $\mathrm{Ba}$ (circles) concentrations in a culture of Gloeomargarita lithophora inoculated in BG-11.Error bars are smaller than symbols. 


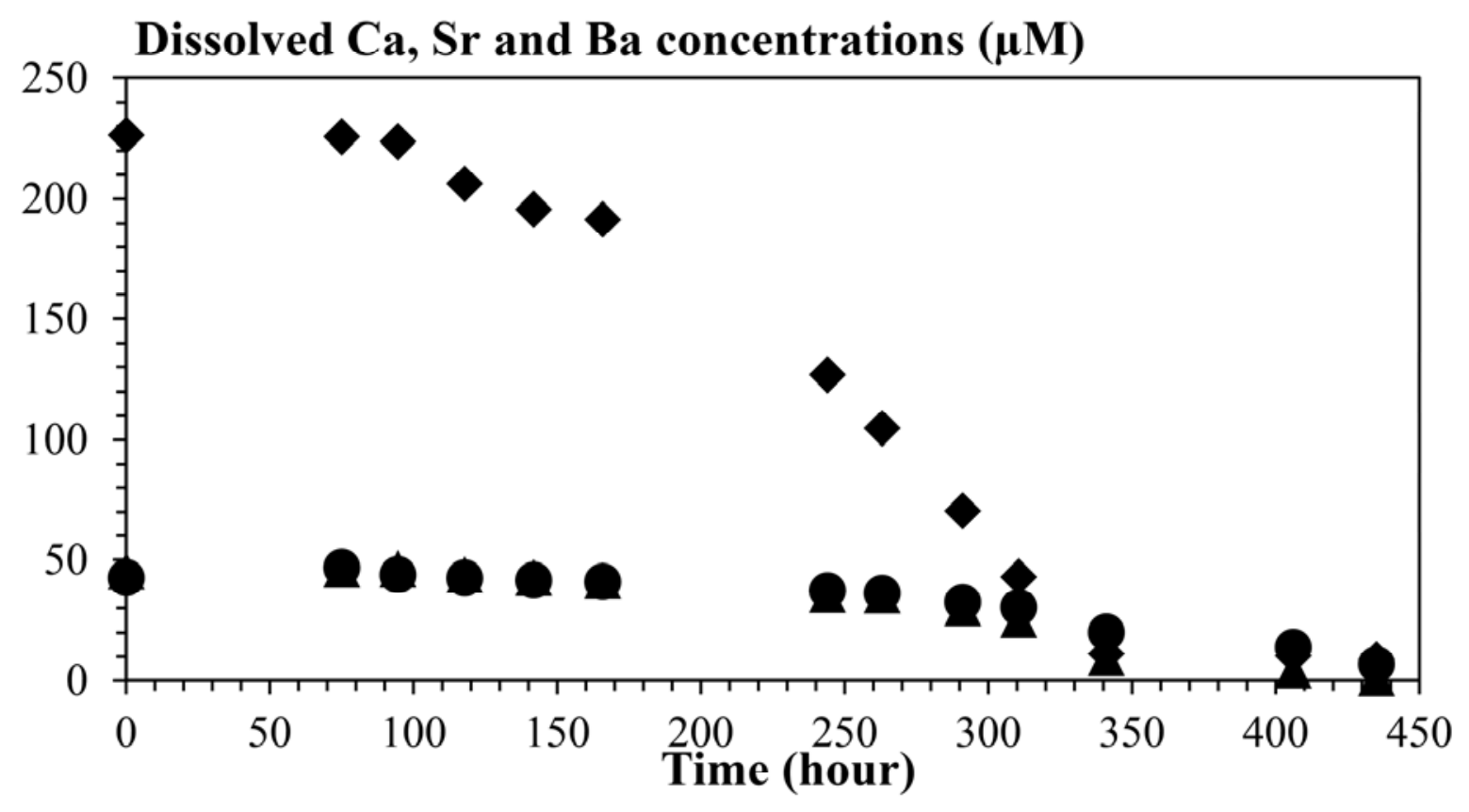

398

Figure 2. Time evolution of the concentrations of dissolved $\mathrm{Ca}$ (diamonds), $\mathrm{Sr}$ (triangles) and $\mathrm{Ba}$ (circles) concentrations in a culture of Cyanothece sp. inoculated in BG-11. Analytical standard deviations are smaller than the symbol sizes. 

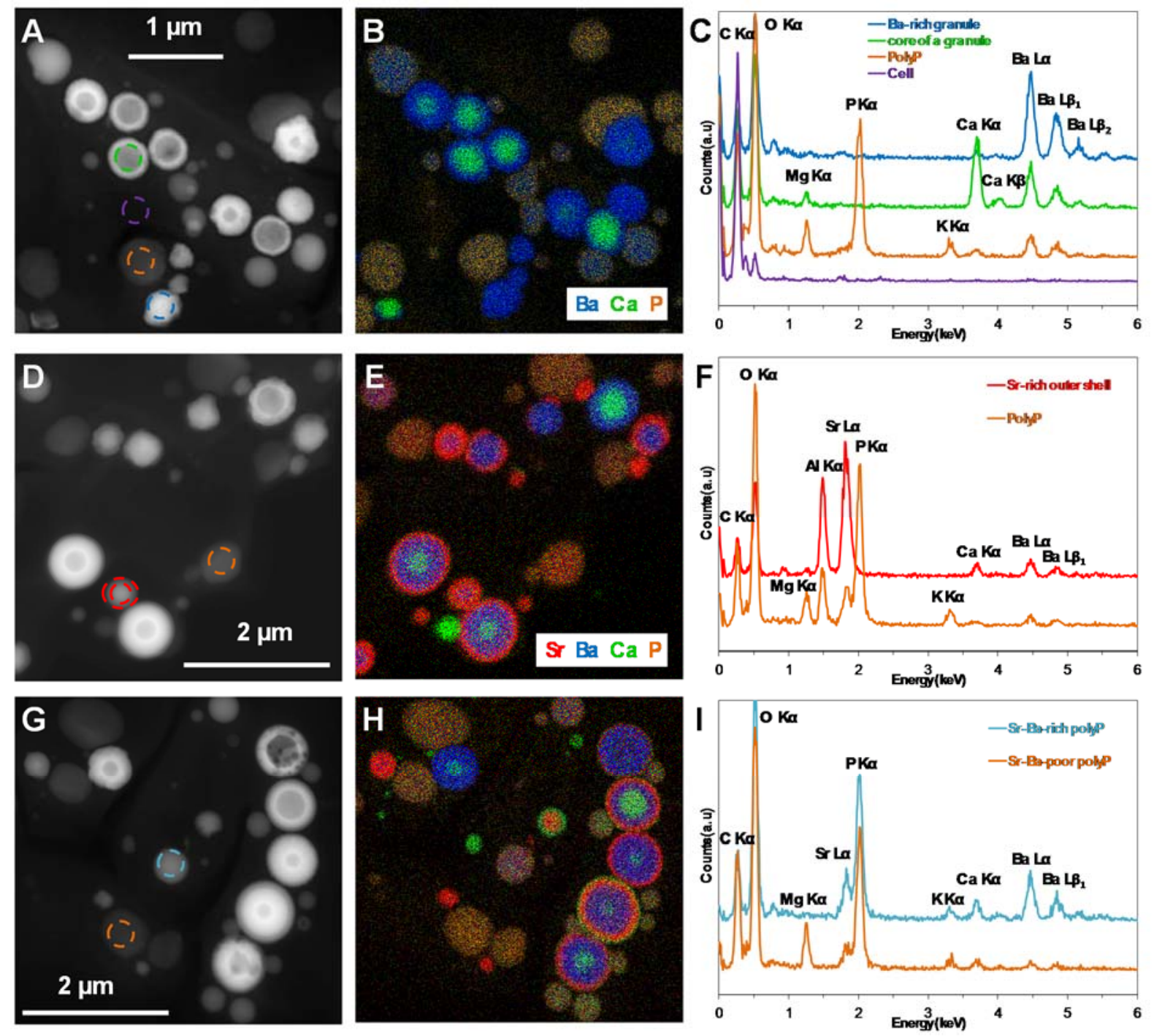

Figure 3. STEM and EDXS analyses of Gloeomargarita lithophora cells collected after $75 \mathrm{~h}$ of culture during the Ba uptake stage (A, B and C), during the Sr uptake stage (D, E and F) and during theca uptake stage (G, H and I). (A, D and G) STEM-HAADF Image of cells showing layered carbonate granules. Colored circles show the different areas analyzed by EDXS. (B, E and $\mathrm{H}$ ) Corresponding EDXS map of calcium (green), strontium (red), barium (blue) and phosphorus (orange). (C) EDXS spectra of the Ba-rich granule; a core of a carbonate granule; a PolyP granule and a cellular area comprising no particle shown respectively in A by the blue; green; orange and purple circles. (F) EDXS spectra of a Sr-rich outer shell of a granule and a PolyP particle shown respectively by the red and the orange circles in D. Al comes from the 
sample holder.(I) EDX spectra of the PolyP granules shown by the orange and blue circles in G.
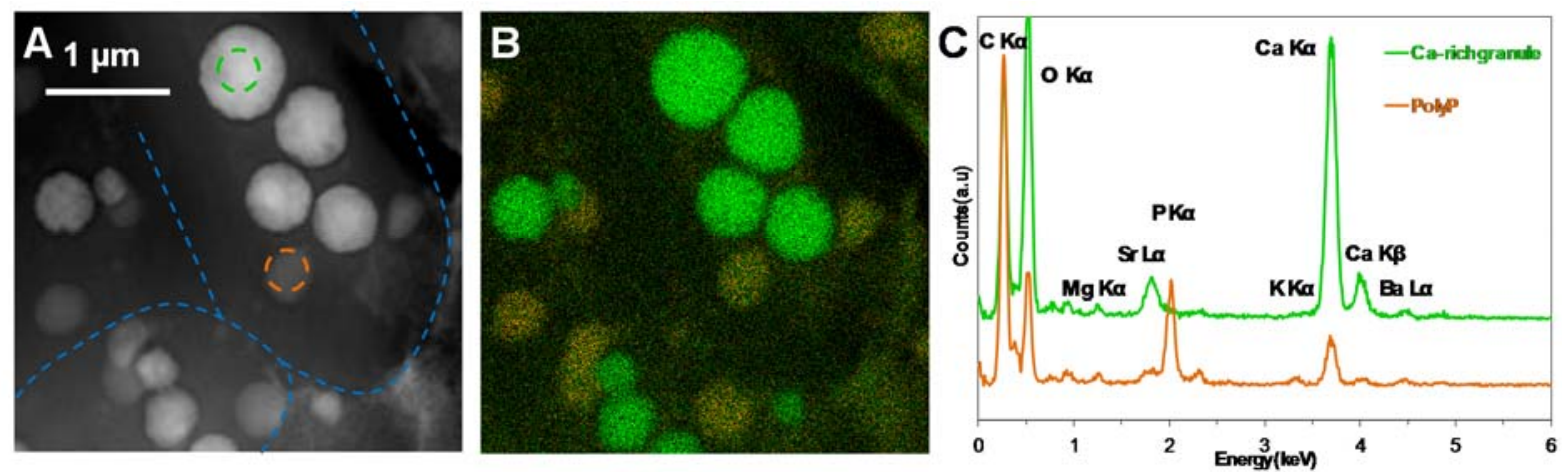

Figure 4. STEM analyses of two Cyanothece sp. cells cultured for $310 \mathrm{~h}$ in BG-11 medium with $50 \mu \mathrm{M}$ of strontium and $50 \mu \mathrm{M}$ of barium. (A) STEM image in the HAADF mode. Circles indicate the carbonate and PolyP granules on which EDXS spectra shown in C were measured.

(B) Corresponding EDXS map of calcium (green) and phosphorus (orange). (C) EDX spectra of a carbonate granule and of a PolyP granule, respectively shown by the green and the orange circles in $\mathrm{A}$.

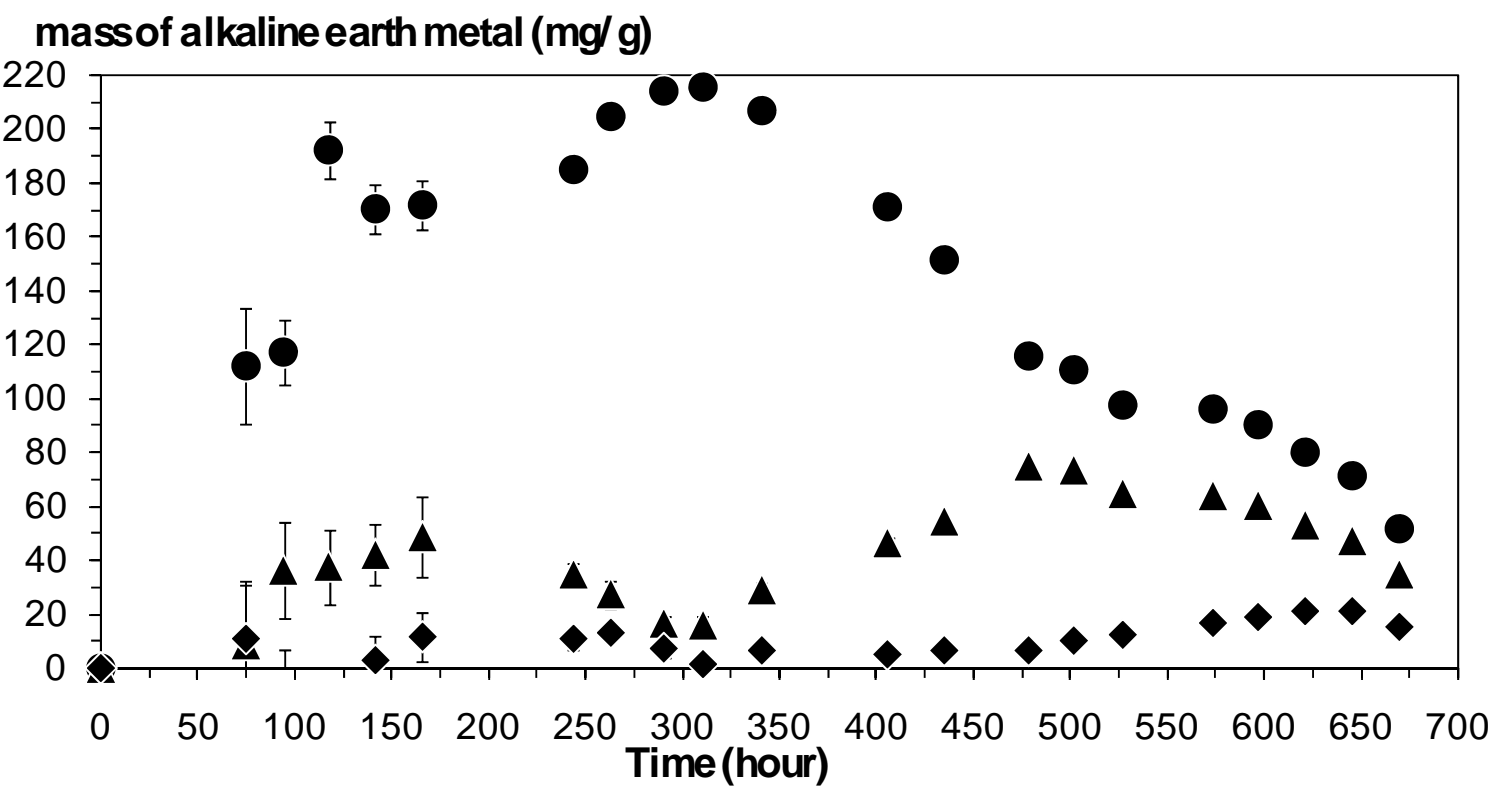


Figure 5. Time evolution of the mass of bioaccumulated $\mathrm{Ba}$ (circles), $\mathrm{Sr}$ (triangles) and $\mathrm{Ca}$

425 (diamonds) per total dry mass of the cells $(\mathrm{mg} / \mathrm{g})$ for a culture of Gloeomargarita lithophora in errors bars are smaller than the size of the symbols.

\begin{tabular}{|c|c|c|c|c|c|c|c|c|}
\hline \multirow[b]{2}{*}{$\begin{array}{l}\text { Type of organism } \\
\text { / material }\end{array}$} & \multirow[b]{2}{*}{ Name } & \multirow{2}{*}{$\begin{array}{c}\begin{array}{c}\text { Maximum } \\
\text { uptake rate }\end{array} \\
\text { (fmol/h/cell) }\end{array}$} & \multicolumn{2}{|c|}{ Maximum uptake } & \multicolumn{2}{|c|}{$\begin{array}{l}\text { Maximum } \\
\text { remediation }\end{array}$} & \multirow{2}{*}{$\begin{array}{l}\text { Associated } \\
\text { mechanism }\end{array}$} & \multirow[b]{2}{*}{ References } \\
\hline & & & $\begin{array}{c}\text { (mg/g of } \\
\text { dry } \\
\text { matter) }\end{array}$ & (fmol/cell) & (\%) & $(\mu \mathrm{M})$ & & \\
\hline \multicolumn{9}{|l|}{ Strontium } \\
\hline $\begin{array}{l}\text { Non organic } \\
\text { material }\end{array}$ & $\begin{array}{l}\text { Layered metal } \\
\text { sulfides }\end{array}$ & & & & 99.4 & 756 & & 13 \\
\hline Aquatic plant & E. densa We2 & & 0.0009 & & 33.9 & & Adsorption & 14 \\
\hline Algae & B. maxima & & 15.9 & & & & $\begin{array}{l}\text { Intracellular } \\
\text { accumulation }\end{array}$ & 31 \\
\hline Algae & S. spinosus & & 2.5 & & 76 & 787 & Adsorption & 23 \\
\hline Yeast & S. cerevisiae & 1.2 & 20 & 0.315 & 85 & & $\begin{array}{l}\text { Intracellular } \\
\text { accumulation and } \\
\text { adsorption }\end{array}$ & 30,36 \\
\hline Desmid & C. moniliferum & 1.7 & $2^{*}$ & 140 & & & Intracellular sulfate & 32,59 \\
\hline Micro-algae & $\begin{array}{l}\text { O. sp. Nak } \\
1001\end{array}$ & & 0.0029 & & 36.3 & & Adsorption & 14 \\
\hline Bacterium & H. sp. SR4 & & & & 80 & & Extracellular calcite & 26 \\
\hline Bacterium & $\begin{array}{l}\text { B. pasteurii } \\
\text { ATCC } 11859\end{array}$ & & & & 36 & 40 & Extracellular calcite & 25 \\
\hline Bacterium & $\begin{array}{l}\text { S. pasteurii } \\
\text { ATCC } 11859\end{array}$ & & & & 59 & & Extracellular calcite & 27 \\
\hline Cyanobacterium & $\begin{array}{l}\text { S. ocellatum } \\
\text { NIES } 2131\end{array}$ & & 0.0219 & & 41.3 & & Adsorption & 14 \\
\hline Cyanobacterium & N. carneum & & 0.00225 & & 97.8 & & Adsorption & 21 \\
\hline Cyanobacterium & G. lithophora & 0.079 & 75 & 35 & 100 & 250 & $\begin{array}{l}\text { Intracellular } \\
\text { amorphous } \\
\text { carbonates }\end{array}$ & \\
\hline \multicolumn{9}{|l|}{ Barium } \\
\hline Algae & B. maxima & & 3.79 & & & & $\begin{array}{l}\text { Intracellular } \\
\text { accumulation }\end{array}$ & 31 \\
\hline Desmid & C. moniliferum & & $46 *$ & 2112 & & & Intracellular sulfate & 60 \\
\hline Cyanobacterium & G. lithophora & & 220 & 64 & 100 & 250 & $\begin{array}{l}\text { Intracellular } \\
\text { amorphous } \\
\text { carbonates }\end{array}$ & \\
\hline
\end{tabular}

${ }^{*}$ calculated using a cell volume of $125,600 \mu \mathrm{m}^{3}$ and Kreger and Boeré (1969). ${ }^{58}$ 


\section{ASSOCIATED CONTENT}

\section{Supporting Information}

Data on culture replicates, composition of polyphosphate inclusions, size distributions of carbonate inclusions, data on cultures of $G$. lithophora with $250 \mu \mathrm{M}$ of $\mathrm{Sr}$ and Ba are shown as supporting information (11 figures and 1 Table). This material is available free of charge via the Internet at http://pubs.acs.org.

\section{AUTHOR INFORMATION}

\section{Corresponding Author}

*K. Benzerara. Email: karim.benzerara@impmc.upmc.fr. Tel: +33 1-44-27-75-42

\section{Notes}

The authors declare no competing financial interest.

\section{Author Contributions}

The manuscript was written through contributions of all authors. All authors have given approval to the final version of the manuscript.

\section{ACKNOWLEDGMENTS}

Nithavong Cam was supported by French state funds managed by the ANR within the Investissements d'Avenir program under reference ANR-11-IDEX-0004-02 (Cluster of Excellence MATISSE). Karim Benzerara has been supported by funding from the European Research Council under the European Community's Seventh Framework Programme (FP7/2007-2013 Grant Agreement no.307110 - ERC CALCYAN). The TEM facility at 
IMPMC was purchased owing to a support by Region Ile-de-France grant SESAME $2000 \mathrm{E}$ 1435.

\section{REFERENCES}

(1) McDonough, W. F.; Sun, S. The composition of the Earth. Chem. Geol. 1995, 120 (3-4), 223-253.

(2) Odum, H. T. Notes on the Strontium Content of Sea Water, Celestite Radiolaria, and Strontianite Snail Shells. Science 1951, 114 (2956), 211-213.

(3) Walker, J. B. Inorganic micronutrient requirements of Chlorella: I. Requirements for calcium (or strontium), copper, and molybdenum. Arch. Biochem. Biophys. 1953, 46 (1), $1-11$.

(4) Bowen, H. J. M.; Dymond, J. A. Strontium and Barium in Plants and Soils. Proc. R. Soc. Lond. B Biol. Sci. 1955, 144 (916), 355-368.

(5) Dahl, S. G.; Allain, P.; Marie, P. J.; Mauras, Y.; Boivin, G.; Ammann, P.; Tsouderos, Y.; Delmas, P. D.; Christiansen, C. Incorporation and distribution of strontium in bone. Bone 2001, 28 (4), 446-453.

(6) Reginster, J. Y.; Deroisy, R.; Dougados, M.; Jupsin, I.; Colette, J.; Roux, C. Prevention of Early Postmenopausal Bone Loss by Strontium Ranelate: The Randomized, TwoYear, Double-Masked, Dose-Ranging, Placebo-Controlled PREVOS Trial. Osteoporos. Int. 2002, 13 (12), 925-931.

(7) Verberckmoes, S. C.; Broe, M. E. D.; D'Haese, P. C. Dose-dependent effects of strontium on osteoblast function and mineralization. Kidney Int. 2003, 64 (2), 534-543.

(8) Vakulovsky, S. M.; Nikitin, A. I.; Chumichev, V. B.; Katrich, I. Y.; Voitsekhovich, O. A.; Medinets, V. I.; Pisarev, V. V.; Bovkum, L. A.; Khersonsky, E. S. Cesium-137 and strontium- 90 contamination of water bodies in the areas affected by releases from the chernobyl nuclear power plant accident: an overview. J. Environ. Radioact. 1994, 23 (2), $103-122$.

(9) Casacuberta, N.; Masqué, P.; Garcia-Orellana, J.; Garcia-Tenorio, R.; Buesseler, K. O. ${ }^{90} \mathrm{Sr}$ and ${ }^{89} \mathrm{Sr}$ in seawater off Japan as a consequence of the Fukushima Dai-ichi nuclear accident. Biogeosciences 2013, 10 (6), 3649-3659.

(10) Manos, M. J.; Ding, N.; Kanatzidis, M. G. Layered metal sulfides: Exceptionally selective agents for radioactive strontium removal. Proc. Natl. Acad. Sci. 2008, 105 (10), 3696-3699.

(11) Fukuda, S.; Iwamoto, K.; Atsumi, M.; Yokoyama, A.; Nakayama, T.; Ishida, K.; Inouye, I.; Shiraiwa, Y. Global searches for microalgae and aquatic plants that can eliminate radioactive cesium, iodine and strontium from the radio-polluted aquatic environment: a bioremediation strategy. J. Plant Res. 2014, 127 (1), 79-89.

(12) Singh, S.; Eapen, S.; Thorat, V.; Kaushik, C. P.; Raj, K.; D’Souza, S. F. Phytoremediation of 137Cs and 90Sr from solutions and low-level nuclear waste by Vetiveria zizanoides. Ecotoxicol. Environ. Saf. 2008, 69 (2), 306-311.

(13) Phillips, E.J.; Landa, E.R.; Kraemer, T.. Sulfate-Reducing Bacteria Release Barium and Radium from Naturally Occurring Radioactive Material in Oil-Field Barite. Geomicrobiol. J. 2001, 18 (2), 167-182. 
(14) Magalhães, M. O. L.; Sobrinho, N. M. B. do A.; Zonta, E.; Lima, L. da S.; Paiva, F. S. D. de. Mobilidade de bário em solo tratado com sulfato de bário sob condição de oxidação e redução. Quím. Nova 2011, 34 (9), 1544-1549.

(15) Reeves, A. L. Barium. Handb. Toxicol. Met. 1986, 2, 84-94.

(16) Baldi, F.; Pepi, M.; Burrini, D.; Kniewald, G.; Scali, D.; Lanciotti, E. Dissolution of Barium from Barite in Sewage Sludges and Cultures of Desulfovibrio desulfuricans. Appl. Environ. Microbiol. 1996, 62 (7), 2398-2404.

(17) Peek, S.; Clementz, M.T. $\mathrm{Sr} / \mathrm{Ca}$ and $\mathrm{Ba} / \mathrm{Ca}$ variations in environmental and biological sources: A survey of marine and terrestrial systems. Geochim. Cosmochim. Acta 2012, 95, 36-52.

(18) Sih, T.L.; Kingsford, M.J. Near-reef elemental signals in the otoliths of settling Pomacentrus amboinensis (Pomacentridae). Coral Reefs. 2016, 35 (1), 303-315.

(19) Bahr, A.; Schonfeld, J.; Hoffmann, J.; Voigt, S.; Aurahs, R.; Kucera, M.; Flogel, S.; Jentzen, A.; Gerdes, A. Comparison of $\mathrm{Ba} / \mathrm{Ca}$ and delta $\mathrm{O}-18$ (water) as freshwater proxies: A multi-species core-top study on planktonic foraminifera from the vicinity of the Orinoco River mouth. Earth and Planet. Sci Lett. 2013, 383, 45-57.

(20) Paytan, A.; Griffith, E.M. Marine barite: recorder of variations in ocean export productivity. Deep-Sea Res.II, 2007, 54, 687-705.

(21) von Allmen, K.; Böttcher, M.E.; Samankassou E., Nägler T.F. Barium isotope fractionation in the global barium cycle: First evidence from barium minerals and precipitation experiments. Chem. Geol. 2010, 277, 70-77.

(22) Cao, Z.; Siebert, C.; Hathorne, E.C.; ; Dai, M.H.; Frank, M. Constraining the oceanic barium cycle with stable barium isotopes. Earth and Planet. Sci Lett. 2016, 434, 1-9.

(23) Griffith, E.M.; Paytan, A. Barite in the ocean - occurrence, geochemistry and palaeoceanographic applications. Sedim., 2012, 59, 1817-1835.

(24) Frančišković-Bilinski, S.; Bilinski, H.; Grbac, R.; Žunić, J.; Nečemer, M.; Hanžel, D. Multidisciplinary work on barium contamination of the karstic upper Kupa River drainage basin (Croatia and Slovenia); calling for watershed management. Environ. Geochem. Health 2007, 29 (1), 69-79.

(25) Pohl, P.; Schimmack, W. Adsorption of Radionuclides (134Cs, 85Sr, 226Ra, 241Am) by Extracted Biomasses of Cyanobacteria (Nostoc carneum, $N$. insulare, Oscillatoria geminata and Spirulina laxis-Sima) and Phaeophyceae (Laminaria digitata and L. japonica; Waste Products from Alginate Production) at Different pH. J. Appl. Phycol. 2006, 18 (2), 135-143.

(26) Dabbagh, R.; Ghafourian, H.; Baghvand, A.; Nabi, G. R.; Riahi, H.; Ahmadi Faghih, M. A. Bioaccumulation and biosorption of stable strontium and $90 \mathrm{Sr}$ by Oscillatoria homogenea cyanobacterium. J. Radioanal. Nucl. Chem. 2007, 272 (1), 53-59.

(27) Liu, M.; Dong, F.; Kang, W.; Sun, S.; Wei, H.; Zhang, W.; Nie, X.; Guo, Y.; Huang, T.; Liu, Y. Biosorption of Strontium from Simulated Nuclear Wastewater by Scenedesmus spinosus under Culture Conditions: Adsorption and Bioaccumulation Processes and Models. Int. J. Environ. Res. Public. Health 2014, 11 (6), 6099-6118.

(28) Lee, S. Y.; Jung, K.-H.; Lee, J. E.; Lee, K. A.; Lee, S.-H.; Lee, J. Y.; Lee, J. K.; Jeong, J. T.; Lee, S.-Y. Photosynthetic biomineralization of radioactive $\mathrm{Sr}$ via microalgal $\mathrm{CO}_{2}$ absorption. Bioresour. Technol. 2014, 172, 449-452.

(29) Fujita, Y.; Redden, G. D.; Ingram, J. C.; Cortez, M. M.; Ferris, F. G.; Smith, R. W. Strontium incorporation into calcite generated by bacterial ureolysis1. Geochim. Cosmochim. Acta 2004, 68 (15), 3261-3270. 
(30) Achal, V.; Pan, X.; Zhang, D. Bioremediation of strontium (Sr) contaminated aquifer quartz sand based on carbonate precipitation induced by Sr resistant Halomonas sp. Chemosphere 2012, 89 (6), 764-768.

(31) Lauchnor, E. G.; Schultz, L. N.; Bugni, S.; Mitchell, A. C.; Cunningham, A. B.; Gerlach, R. Bacterially Induced Calcium Carbonate Precipitation and Strontium Coprecipitation in a Porous Media Flow System. Environ. Sci. Technol. 2013, 47 (3), 1557-1564.

(32) Nehrke, G.; Reichart, G. J.; Van Cappellen, P.; Meile, C.; Bijma, J. Dependence of calcite growth rate and Sr partitioning on solution stoichiometry: Non-Kossel crystal growth. Geochim. Cosmochim. Acta 2007, 71 (9), 2240-2249.

(33) Langer, G.; Nehrke, G.; Thoms, S.; Stoll, H. Barium partitioning in coccoliths of Emiliania huxleyi. Geochim. Cosmochim. Acta 2009, 73 (10), 2899-2906.

(34) Takahashi, S.; Aizawa, K.; Nakamura, S.; Nakayama, K.; Fujisaki, S.; Watanabe, S.; Satoh, H. Accumulation of alkaline earth metals by the green macroalga Bryopsis maxima. BioMetals 2015, 28 (2), 391-400.

(35) Krejci, M. R.; Wasserman, B.; Finney, L.; McNulty, I.; Legnini, D.; Vogt, S.; Joester, D. Selectivity in biomineralization of barium and strontium. J. Struct. Biol. 2011, 176 (2), 192-202.

(36) Sternberg, E.; Tang, D.; Ho, T.-Y.; Jeandel, C.; Morel, F. M. M. Barium uptake and adsorption in diatoms. Geochim. Cosmochim. Acta 2005, 69 (11), 2745-2752.

(37) Kaduková, J.; Virčíková, E. Comparison of differences between copper bioaccumulation and biosorption. Environ. Int. 2005, 31 (2), 227-232.

(38) Avery, S. V.; Smith, S. L.; Ghazi, A. M.; Hoptroff, M. J. Stimulation of strontium accumulation in linoleate-enriched Saccharomyces cerevisiae is a result of reduced $\mathrm{Sr} 2+$ efflux. Appl. Environ. Microbiol. 1999, 65 (3), 1191-1197.

(39) Wilcock, J. R.; Perry, C. C.; Williams, R. J. P.; Mantoura, R. F. C. Crystallographic and Morphological Studies of the Celestite Skeleton of the Acantharian Species Phyllostaurus siculus. Proc. R. Soc. Lond. B Biol. Sci. 1988, 233 (1273), 393-405.

(40) Schröter, K.; Läuchli, A.; Sievers, A. Mikroanalytische Identifikation von BariumsulfatKristallen in den Statolithen der Rhizoide von Chara fragilis, Desv. Planta 1975, 122 (3), 213-225.

(41) Hemmersbach, R.; Volkmann, D.; Häder, D.-P. Graviorientation in Protists and Plants. J. Plant Physiol. 1999, 154 (1), 1-15.

(42) Gooday, A. J.; Nott, J. A. Intracellular Barite Crystals in Two Xenophyophores, Aschemonella ramuliformis and Galatheammina sp. (Protozoa: Rhizopoda) With Comments on the Taxonomy of A. Ramuliformis. J. Mar. Biol. Assoc. U. K. 1982, 62 (3), 595-605.

(43) Couradeau, E.; Benzerara, K.; Gerard, E.; Moreira, D.; Bernard, S.; Brown, G. E.; Lopez-Garcia, P. An Early-Branching Microbialite Cyanobacterium Forms Intracellular Carbonates. Science 2012, 336 (6080), 459-462.

(44) Li, J.; Margaret Oliver, I.; Cam, N.; Boudier, T.; Blondeau, M.; Leroy, E.; Cosmidis, J.; Skouri-Panet, F.; Guigner, J.-M.; Férard, C.; et al. Biomineralization Patterns of Intracellular Carbonatogenesis in Cyanobacteria: Molecular Hypotheses. Minerals 2016, $6(1), 10$.

(45) Cam, N.; Georgelin, T.; Jaber, M.; Lambert, J.-F.; Benzerara, K. In vitro synthesis of amorphous $\mathrm{Mg}-, \mathrm{Ca}-, \mathrm{Sr}-$ and Ba-carbonates: What do we learn about intracellular calcification by cyanobacteria? Geochim. Cosmochim. Acta 2015, 161, 36-49.

(46) Benzerara, K.; Skouri-Panet, F.; Li, J.; Férard, C.; Gugger, M.; Laurent, T.; Couradeau, E.; Ragon, M.; Cosmidis, J.; Menguy, N.; et al. Intracellular Ca-carbonate biomineralization is widespread in cyanobacteria. Proc. Natl. Acad. Sci. 2014, 111 (30), 10933-10938. 
(47) Ragon, M.; Benzerara, K.; Moreira, D.; Tavera, R.; Lopez-Garcia, P. 16S rDNA-based analysis reveals cosmopolitan occurrence but limited diversity of two cyanobacterial lineages with contrasted patterns of intracellular carbonate mineralization. Front. Microbiol. 2014, 5, 331.

(48) Rippka, R.; Deruelles, J.; Waterbury, J. B.; Herdman, M.; Stanier, R. Y. Generic Assignments, Strain Histories and Properties of Pure Cultures of Cyanobacteria. J. Gen. Microbiol. 1979, 111 (1), 1-61.

(49) Jaquet, J.-M.; Nirel, P.; Martignier, A. Preliminary investigations on picoplanktonrelated precipitation of alkaline-earth metal carbonates in meso-oligotrophic Lake Geneva (Switzerland). J. Limnol. 2013, 72 (3), 592-605.

(50) Fernandez-Martinez, A.; Kalkan, B.; Clark, S. M.; Waychunas, G. A. Pressure-Induced Polyamorphism and Formation of "Aragonitic" Amorphous Calcium Carbonate. Angew. Chem. Int. Ed. 2013, 52 (32), 8354-8357.

(51) Krejci, M. R.; Finney, L.; Vogt, S.; Joester, D. Selective Sequestration of Strontium in Desmid Green Algae by Biogenic Co-precipitation with Barite. ChemSusChem 2011, 4 (4), 470-473.

(52) Kirichok, Y.; Krapivinsky, G.; Clapham, D. E. The mitochondrial calcium uniporter is a highly selective ion channel. Nature 2004, 427 (6972), 360-364.

(53) Reusch, R. N.; Huang, R.; Bramble, L. L. Poly-3-hydroxybutyrate/polyphosphate complexes form voltage-activated $\mathrm{Ca}^{2+}$ channels in the plasma membranes of Escherichia coli. Biophys. J. 1995, 69 (3), 754-766.

(54) Vrettos, J. S.; Stone, D. A.; Brudvig, G. W. Quantifying the Ion Selectivity of the $\mathrm{Ca}^{2+}$ Site in Photosystem II: Evidence for Direct Involvement of $\mathrm{Ca}^{2+}$ in $\mathrm{O}_{2}$ Formation ${ }^{\dagger}$. Biochemistry (Mosc.) 2001, 40 (26), 7937-7945.

(55) Falke, J. J.; Snyder, E. E.; Thatcher, K. C.; Voertler, C. S. Quantitating and engineering the ion specificity of an EF-hand-like calcium binding site. Biochemistry (Mosc.) 1991, 30 (35), 8690-8697.

(56) Henikoff, S.; Greene, E. A.; Pietrokovski, S.; Bork, P.; Attwood, T. K.; Hood, L. Gene Families: The Taxonomy of Protein Paralogs and Chimeras. Science 1997, 278 (5338), 609-614.

(57) Gonzalez-Muñoz, M. T.; Martinez-Ruiz, F.; Morcillo, F.; Martin-Ramos, J. D.; Paytan, A. Precipitation of barite by marine bacteria: A possible mechanism for marine barite formation. Geology 2012, 40 (8), 675-678.

(58) Kreger, D. R.; Boeré, H. Some Observations on Barium Sulphate in Spirogyra*. Acta Bot. Neerlandica 1969, 18 (1), 143-151. 